\title{
2 \\ Bennelong and Gogy: Strategic brokers in colonial New South Wales
}

\section{Introduction: Intersecting and parallel lives}

On the road between Parramatta and Prospect a meeting took place on Monday last for the purpose of inflicting punishment on a native well known at the above settlements by the name of Goguey ... His crime was defensible upon custom immemorial, but so likewise was his extraordinary mode of arraignment an event consequent upon the former. Perceiving an unusual degree of rancour in the menaces of his judges, he endeavoured for a short time to avoid them by retiring; but being closely pursued he formed his resolution, and made a stand, with two adherents near him. The spears of his adversaries were barbed and rough-glazed, and three at once advancing upon him until within ten or twelve feet, he caught the first thrown on his target, but the second, discharged by Bennelong, entered above the hip, and passed through the side, so as to be afterwards extracted; but the third thrown by Nanbery as he wheeled to defend himself from the former, entered the back below the loins; when perceiving that his seconds had left him, he in a transport of rage and anguish turned his resentment upon those from whom he expected assistance but had deceived him, and then exhausted, fell.

Sydney Gazette and New South Wales Advertiser, 17 March 1805 
Many historians have outlined the rationale behind European colonists' use of Indigenous guides. It has long been acknowledged that the guides' knowledge of the local environments informed and safeguarded the Europeans, as they played a crucial role in ensuring the expeditions had sufficient water and food. Increasingly, historians have recognised that such individuals were not mere guides, but rather acted as intermediaries, for their knowledge of local Indigenous languages and protocols allowed them to communicate the aims and interests of the explorers to any wary Indigenous people encountered. Historians have begun to map out the different reasons why Aboriginal people would become intermediaries for imperial and colonial expeditions, especially those who became known as professional guides, leading multiple excursions and traversing vast distances. Some of the broader synthetic studies such as Henry Reynolds's With the White People and, more recently, Dane Kennedy's The Last Blank Spaces have posited a range of factors, such as the temptation of material rewards, the desire for adventure, and, as Kennedy argues, the sad fact that some were 'deracinated', removed from their own kin networks, and had few alternative options. ${ }^{1}$ Such typological studies are useful for sketching out the history of Aboriginal guides, but in order to gain deeper insights into the more complex motivations of Indigenous people to join expeditions, we need more detailed biographical portraits of the individual intermediaries and brokers, considering the Indigenous worlds that framed an individual intermediary's outlook, interests and intentions.

This chapter will investigate the experiences of two early Indigenous intermediaries: the infamous Wangal man Bennelong, the first intermediary between the local Eora clans and the British First Fleet (which, under the command of Governor Arthur Phillip, established the New South Wales colony); and his contemporary, the lesser known Dharawal man Gogy, who acted as a guide for NSW Corps Lieutenant Francis Barrallier on his colonial expedition into the Blue Mountains. Bennelong has long been subject to historical and biographical study, and long-standing representations of him as a tragic figure destroyed by alcohol have in recent years been replaced by the view that he was a highly mercurial yet strategic individual who was aware of

1 Reynolds 1990: 5-40; Kennedy 2013: 159-194. 
his important role as a cultural broker. ${ }^{2}$ Gogy, on the other hand, has been dismissed by the few historians who have discussed him as 'obnoxious' and seen as a failed intermediary who 'undermined' the expedition. ${ }^{3}$ My aim is to tease out the parallels in their actions and the relationships that Bennelong and Gogy deliberately cultivated with Phillip and Barrallier, in order to suggest that they were both driven by their standing in their own Indigenous polities and saw their roles as intermediaries as a means of elevating their status. Our knowledge of these two individuals derives from Western accounts. Yet most archival records about Aboriginal people are fragmentary, and written sources are often mediated through colonial prejudices, interests and assumptions. Consequently, informed speculation and 'reading against the grain' is often necessary in fleshing out the lives of past Aboriginal individuals. As Lynette Russell observes in her reflections on writing the biography of her Aboriginal grandmother, 'imagination plays an important role in constructing her narrative'.${ }^{4}$ In this chapter, I argue that it is crucial to view intermediaries such as Bennelong and Gogy not only in terms of how they contributed to or were ruined by colonial society, but also in terms of their Indigenous life worlds.

\section{Bennelong the cultural broker}

Bennelong was a key cultural broker in the early Port Jackson colony. ${ }^{5}$ He was a member of the Wangal, one of the Eora clans whose territory spanned the southern side of Port Jackson between Darling Harbour and Rose Hill. He first became known to Governor Arthur Philip, who established the British colony in Sydney in January 1788, in November 1789 when he was 'about 26 years old, of good stature and stoutly made'. The British were initially struck by his appearance, as he had 'a bold intrepid countenance which bespoke defiance and revenge' ${ }^{6}$

\footnotetext{
2 See Clendinnen 2003; Dortins 2009; Smith 2009; Turnbull 2009.

3 Lhuedé 2003: 13; Thomas 2003: 87.

4 Russell 2001: 148.

5 Bennelong advised the British colonists that he had five names 'Wol-lar-re-barre, Wog-ultrowe, Ban-nel-lon, Boinba, [and] Bunde-bunda', according to Governor Phillip. Tench reported that his preferred name was Woollarawarre, however, he was most often referred to as Bennelong. See Smith 2009: 9.

6 Tench 1979: 159.
} 
Phillip had long been eager to establish cordial relations with the local Eora Aboriginal people, not only because he had been instructed by the Admiralty to 'conciliate their affections', but also because he believed he could bring them 'into a voluntary subjection' through 'humane' and 'honourable' conduct, and prove that, in contrast to the Spanish conquest, 'a sanguinary temper was no longer to disgrace the European settlers in countries newly discovered'.$^{7}$ This ambition had been frustrated by the Eora's refusal to come into the colony, and their seemingly opportunistic attacks on lone or unarmed convicts. So in December 1788, Phillip decided to induce a definitive response from the Eora by 'capturing some of them by force'. He believed that this kidnapping would possibly bring tensions to a head and trigger a more decisive confrontation, but hoped that it would instead 'induce an intercourse' once the Aborigines realised that the captives had been treated with 'mildness and indulgence' ${ }^{8}$ Unfortunately for the British the first potential intermediary they captured, Arabanoo (also known as Manly), died whilst in their custody, so could not advocate the colonists' benevolence to the Eora people. ${ }^{9}$

The following November saw Phillip decide to try the same strategy, with the added hope that the new captives would inform the governor 'whether or not the country possessed any resources by which life might be prolonged'. ${ }^{10}$ So Lieutenant William Bradley was dispatched and managed to carry off 'without opposition, two fine young men', Bennelong and Coleby. Despite the governor's instructions to 'treat them indulgently, and guard them strictly', Coleby escaped within the first week. Once alone it seemed to the British that Bennelong 'pretended, nay, at particular moments, perhaps [even] felt satisfaction in his new state'. ${ }^{11}$

Bennelong developed a close relationship with Governor Phillip, who took an active role teaching him English as well as the arts of British decorum and etiquette. Bennelong impressed the British with his

\footnotetext{
$7 \quad$ Phillip 1968: 44-45, 68.

8 Tench 1979: 138.

9 Arabanoo was captured on 31 December 1788 and died in May 1789 from smallpox. During this time two Aboriginal children, Nanbaree and Bòo-ron (known by the British as Abaroo), came to live in the colony. Both had been discovered by the British with a family member suffering from smallpox who had subsequently passed away. Tench 1979: 139-149.

10 Tench 1979: 158-159.

11 Tench 1979: 159.
} 
quick grasp of the foreign language, leading Watkin Tench, a First Fleet lieutenant, to praise '[h]is powers of mind [which] were certainly far above mediocrity'. Tench observed that ' $\mathrm{h}] \mathrm{e}$ acquired knowledge, both of our manners and language, faster than his predecessor [Arabanoo] had done. He willingly communicated information, sang, danced and capered, told us all the customs of his country and all the details of his family economy'. ${ }^{12}$ During his period of incarceration, Bennelong shared Phillip's table and, unlike Arabanoo and Coleby, developed a taste for alcohol, often enthusiastically toasting the health of his acquaintances. He also entertained the governor by mimicking the 'actions and gestures of every person in [his] family'. ${ }^{13}$ The two men shared regular walks around the governor's grounds, the younger dressed in his favourite red kersey jacket and 'a pair of trowsers' adorned with Phillip's small sword, 'a mark of [the governor's] confidence' in his prospective intermediary. ${ }^{14}$

Throughout his period of incarceration, Bennelong appeared to be a promising future go-between, one who could eventually return to the Eora people and testify to the good intentions of the British colonists, and lead to their 'coming in' to the colony. For instance, unlike Arabanoo, who would not tolerate any injury against his pride, Bennelong appeared to be 'very good-natured, being seldom angry at any jokes that may be passed upon him'. Bennelong's readiness to sing and dance at the officers' behest, the conscientiousness he displayed in learning British manners, and his adoption of Western dress seemed to demonstrate his acceptance of the British and desire to assimilate to their ways. ${ }^{15}$ Governor Phillip also ensured that Bennelong was kept 'in ignorance' of the dire circumstances faced in the early colony, lest he give 'his countrymen such a description of our diminished numbers and diminished strength as would have emboldened them to become more troublesome'. To this end his rations were supplemented with extra fish and ground corn. While he was held captive, the British deemed Bennelong as 'pliant', and 'hardly anyone judged that he would attempt to quit us were the means of escape put within his reach'. ${ }^{16}$ Yet when the opportunity finally arose, after five months

2 Tench 1979: 160.

13 King 1968: 267.

14 King 1968: 269.

15 King 1968: 269.

16 Tench 1979: 161. 
in British custody, he absconded from the colony. After feigning an illness in the middle of the night, Bennelong was allowed outside, and once he 'found himself in a backyard ... he nimbly leaped over a slight paling and bade us adieu'. ${ }^{17}$

However, despite his escape from the colony, Bennelong did eventually become an intermediary, and has been recognised as the most significant cultural broker between the British and the Eora people. Contrary to British expectations, he did not simply become a 'pliant' advocate of their interests. Instead, he attempted to use the British to serve his own personal ambitions. ${ }^{18}$ In Dancing with Strangers Inga Clendinnen reminds us that before Bennelong's capture the Eora clans had been ravaged by a smallpox epidemic that claimed untold lives, and in the wake of this tragedy, 'a radical redrawing of old political arrangements' would have been necessary. ${ }^{19}$ Such a 'redrawing' perhaps provided opportunities for younger individuals, who otherwise would have deferred to the authority of elders, to try and elevate their position. Alternatively, the British presence may have been construed as a potential means of improving one's status; as Clendinnen speculates, Bennelong may have 'decided on trying for an alliance with the strangers shortly after his capture', or even 'toyed with the idea' earlier. She argues that this underlying motive better explains some of his 'actions and reactions', such as his 'tireless boasting of his sexual and fighting prowess', his 'swift adoption of British manners', and his 'use of clothing' ${ }^{20}$ David Turnbull similarly recognises that Bennelong's actions were deliberate and calculated, arguing that 'Bennelong was not a passive subject, he took an active, strategic, part in the spatial politics of positioning the cultural boundary in his role as negotiator and translator' ${ }^{21}$ Through a series of events, and negotiations, Bennelong 'skillfully [wove] the British into a series of reciprocal relations' which significantly advantaged his clan over others and, as Turnbull points out, allowed the Eora to dominate the trade with the British relative to other language groups in the area. ${ }^{22}$ Thus recognising Bennelong's actions as strategic, rather

17 Tench 1979: 167.

18 Inga Clendinnen enthusiastically adopts this notion, suggesting that almost immediately after his capture he decided to try and forge an alliance with the British. Clendinnen 2003: 107.

19 Clendinnen 2003: 106.

20 Clendinnen 2003: 106-107.

21 Turnbull 2009: 394.

22 Turnbull 2009: 399. 
than guileless as the British had, certainly recasts British reports of his actions and behaviours, including his exchange of names with Governor Phillip.

As previously mentioned, Bennelong had forged a close relationship with Phillip which endured after his escape. He even referred to the governor as "Beanga" or Father; and the governor call[ed] him "Dooroow" or Son'. ${ }^{23}$ Bennelong also exchanged names with the governor, a significant custom within Aboriginal society, and not just a 'mark of friendship' as asserted by Tench. Thus he called Phillip by his own preferred name 'Wolarawaree', and in turn adopted 'to himself the name of governor'. ${ }^{24}$ This trading of Aboriginal and English names arguably endowed Bennelong with the authority to act as an intermediary between both societies, and garner prestige and power. Considering this exchange of names as strategic, rather than just as a symbol of friendship, explains some of Bennelong's inexplicable actions. For instance, the first time the British encountered Bennelong again after his escape was at a whale feast at Manly Cove.

Before the 200-odd Aboriginal people gathered on shore, Bennelong ostentatiously presented the sailors with a piece of whale meat as a present for the governor. ${ }^{25}$ His gift of whale meat was effective, and Phillip rushed to Manly Cove where Bennelong reminded him of their friendship by performing their traditions and toasting to 'the king'. However, shortly after they were reunited the governor was speared by a visibly agitated man, Wil-le-me-ring. ${ }^{26}$ Phillip perceived this attack as a 'momentary impulse of fear', but was more perplexed by Bennelong, noting that his behaviour in front of the Aboriginal crowd was 'not so easily ... accounted for. He never attempted to interfere when the man took the spear up, or said a single word to prevent him from throwing it.' Yet later, when Bennelong and Coleby were questioned by the British, they 'pretended highly to disapprove the conduct of the man who had thrown the spear, vowing to execute

\footnotetext{
23 King 1968: 269. See also Hunter 1968: 141; Collins 1975: 452; Tench 1979: 160.

24 Tench 1979: 160. While Clendinnen sees Bennelong as politically minded and astute, she views this exchange of names simply as a mark of affection, and not strategic. Clendinnen 2003: 103-104.

25 Phillip 1968: 305.

26 Phillip 1968: 308-311. Clendinnen contests the accepted view that Phillip's spearing was a result of panic, and proposes that Bennelong had staged either a ritualistic spearing contest or Phillip's punishment for British transgressions. This is an interesting opinion, but the prevailing view of the First Fleet diarists was that it was a nervous reaction. Clendinnen 2003: 123-124.
} 
vengeance upon him'. Phillip did not understand why his esteemed friend had not leapt to his defence, and was shocked when days later Bennelong bluntly 'enquired if the governor was dead'. Yet, crucially, Bennelong also claimed that he had beaten Wil-le-me-ring after the spearing. ${ }^{27}$ Bennelong's seemingly duplicitous behaviour appears as strategically motivated, and as a determined effort not to turn either the British or the Eora against him. In front of the Aboriginal gathering he behaved as they did, by not reacting to Wil-le-me-ring's attack, yet to the British, he claimed solidarity with Phillip.

Bennelong's reason for adopting 'to himself the name of governor' was to muster British support against his rivals by presenting them as enemies. Phillip observed that 'from the first day he was able to make himself understood he was desirous to have all the [neighbouring] tribe of the Cammeragal killed' ${ }^{28}$ But this demand baffled the British, since he was frequently seen keeping amiable company with the Cameragal ${ }^{29}$ and other clans that he had portrayed as enemies, including those from Botany Bay whom he accused of 'always kill[ing] the white men'. ${ }^{30}$ Perhaps Bennelong's animosity towards the Cameragal was because they played an instrumental role in the yoo-lahng erah-ba-diahng ceremony which marked Aboriginal boys' transition to manhood. ${ }^{31}$ This ceremony was a prestigious event, in which large numbers of Aboriginal people from around the Sydney region would congregate at the 'yoo-lahng', or ceremonial space, and dance through the night, awaiting the arrival of the Cameragal. ${ }^{32}$ The key part of the ceremony, the removal of the front tooth, was performed by the carrahdis, and the British understood that this role was an esteemed 'office' in Eora society. Significantly, Bennelong had boasted to Phillip that he had performed this operation himself: 'Bannelong had a throwing stick which he took pains to shew had been cut for the purpose of knocking

27 Phillip 1968: 308, 310-311. Tench claims that shortly after the spearing Bennelong and Colbee had both been interviewed by some of the boat's crew, and '[l]ike the others, they had pretended highly to disapprove the conduct of the man who had thrown the spear, vowing to execute vengeance upon him' (my emphasis). Tench 1979: 181.

28 Phillip 1968: 323-327.

29 While there are different historical spellings for this clan, the most widely accepted spelling is now 'Cameragal'. See, for example, Aboriginal Heritage Office 2015: 6, 8; Dictionary of Sydney n.d.

30 Phillip 1968: 323-327.

31 The ritual significance of the tooth removal ceremony was indicated by this name, whereas the loss of any other tooth was referred to by the term 'bool-bag-ga'. Collins 1975: 485.

32 Collins 1975: 467. 
out the front tooth, and there was some reason to think he had performed that office'.$^{33}$ Bennelong's attempt to forge an alliance with the British was motivated by his desire to elevate his own position of power in the Eora polity, and eventually 'Governor Phillip began to suspect, though very unwillingly, that there was a great deal of art and cunning in Bennelong'. ${ }^{34}$

Throughout his interactions with the British, Bennelong always appeared to have one eye on his fellow Eora, ensuring that they were witness to the esteem with which the British treated him due to their desire to harness him as an envoy. After his escape, the British did not see him for four months. When they eventually did he was unrecognisable and had grown a long beard. ${ }^{35}$ Before meeting with Phillip he requested a razor so he could shave, but was instead given scissors with which he trimmed his beard. Yet one week later when he again met some officers, his behaviour was markedly different. This time, in front of his family and friends, some of whom were 'timorous and unwilling to approach', Bennelong made a show of his familiarity with the British. After receiving a 'hatchet and a fish' he 'called loudly for' some 'bread and beef', which he offered to the others but only two were willing to taste it. Bennelong then 'made a motion to be shaved', and to the 'great admiration of his countrymen' was promptly shaved by the British barber. Bennelong clearly showed off in front of his countrymen, for they 'laughed and exclaimed' when he was shaved. Yet his performance was also a way of proving his own unique position as go-between, for after watching the British shave Bennelong, none of the others would 'consent to undergo it' themselves. ${ }^{36}$

Yet Bennelong's ostentatious displays were not just intended for his Aboriginal audience, his performances were also directed at the British, Phillip in particular, and were intended to assert and remind the colonists of his own political power. His determined efforts to have his authority recognised by the British came to a head during a protracted dispute over a young woman. Bennelong had kidnapped Boorong and announced that he would kill her in revenge for an

33 Phillip 1968: 332.

34 Phillip 1968: 323-327.

35 Tench 1979: 176.

36 Tench 1979: 183. 
injury inflicted on him by her father. ${ }^{37}$ After Bennelong was seen attacking Boorong several times, the colony's judge advocate David Collins attempted to 'reason' with him, telling 'him that if he killed the girl the governor would kill him'. Bennelong responded by 'mark[ing] with his finger those parts of the head, breast and arms where he said he would wound her, before he cut her head off'. When the governor offered her sanctuary, Boorong indicated that she would instead prefer to go to Bennelong's hut, where other Eora, including a young man thought to be her husband, were staying. After Phillip attempted to make the girl understand that if she went away she would be beat' by Bennelong, Bennelong suddenly promised the governor that he would not hurt her. While the other officers were suspicious of Bennelong's abrupt about-face, the governor believed him and let the woman go with Bennelong. The other officers were astounded by Phillip's decision, and their 'general opinion was that the girl would be sacrificed'. However, 'Governor Phillip himself was fully persuaded that Bannelong [sic] would keep his word' and, to everyone else's surprise, he did and Boorong remained unharmed..$^{38}$ Clendinnen sees this episode as a cultural misunderstanding, arguing that it was Bennelong's attempt to prove to Phillip that he too has a position of authority within the Eora polity, especially when resident within his own house..$^{39}$ Perhaps Bennelong's aim was even to remind the British of the continued jurisdiction of Aboriginal law within the boundaries of the colony, by asserting his right to punish Boorong. Certainly, Bennelong's performance was directed towards Phillip, testing Phillip's determination to publicly affirm their mutual respect and show his faith in Bennelong, and again confirming Bennelong's privileged position in the colony as a key cultural broker.

37 Phillip 1968: 321. Clendinnen sees this episode as a cultural misunderstanding. She argues that this was Bennelong's attempt to prove to Phillip that he too has a position of authority within his own polity, and had a level of autonomy within the colony, especially when resident within his own house.

38 Phillip 1968: 321-323.

39 Clendinnen 2003: 149-151. 


\section{Gogy the obnoxious guide}

In 1802, Gogy was still a young man, as he only had one wife and a young son, but he had already led a turbulent life. ${ }^{40} \mathrm{He}$ belonged to the Dharawal whose territory spanned from Botany Bay southwards to the Shoalhaven River, and inland to Camden, where it bordered the lands of the Gandangara people who lived in the Blue Mountains. At that time it was not known as Dharawal country by the British colonists. They instead named these lands the County of Cumberland, but it was more frequently referred to as 'the Cowpastures', named after the cattle brought from England by the First Fleet to help feed and nourish their new settlement which had instead escaped south-west, running wild in the grasslands created by the local clans over many generations. ${ }^{41}$ By then Gogy had already been exiled from his Dharawal country; instead of facing his punishment for a killing he had been involved in he fled west into Gandangara territory. There he was succoured by Goondel, forming a close relationship with the man who 'provid[ed] for all of his wants with the greatest friendship'. After a 'long time' Gogy returned to the Dharawal, and after 'submitt[ing] himself to the usual punishment' was 'well received'. 'Unfortunately ... [Gogy then] made an incursion with a friend of his' back into Gandangara territory, and the friend, who was also Goondel's enemy, pursued, caught and killed a local woman, and both men then allegedly 'grilled and ate' some of her flesh. ${ }^{42}$ Thus Gogy again fled, this time fearing Goondel's wrath and retribution, heading east, towards the British outpost at Prospect Hill.

It was here in October 1802 that Gogy met the 29-year-old French surveyor Francis Luis Barrallier, telling him this story of his troubled past. At the time, Barrallier was on a brief reconnaissance excursion to the foothills of the Blue Mountains scouting potential depot sites in preparation for his imminent expedition to find a route through the range. Since 1788, when the British had first arrived, the Blue Mountains had served as an impenetrable western boundary of the expanding Port Jackson settlement, and had already defeated numerous British attempts to discover what lay beyond. Barrallier, a Frenchman

40 By 1810 he would have two wives and more than one child. Liston 1988: 58.

41 Liston 1988: 50.

42 Barrallier 1975: 48n. See also Liston 1988: 57; Lhuedé 2003: 13. 
whose Royalist family had escaped the wrath of the early French Revolutionaries' and fled to Britain in 1793, had sailed to Port Jackson in 1801 with the ambition of becoming the colony's Deputy Surveyor General. ${ }^{43}$ On the journey out he met King, who was travelling with his French-speaking family to New South Wales to take up the colony's governorship after John Hunter. Having already established a close connection to King, Barrallier enlisted with the NSW Corps upon arriving in the colony, and soon undertook surveying missions in Bass Strait and the Hunter region. In 1802 he became Governor King's aide de camp. The governor had been particularly keen to discover what lay beyond the Blue Mountains primarily to quell the rumour, as 'wicked as it false', of an inland settlement which had tempted many convict to abscond and seek refuge there. ${ }^{44}$ Barrallier was confident that he could succeed in crossing the mountains even though others had failed because he planned to establish a network of depots. He envisaged that this would allow his expedition to remain in communication with the colony, and more importantly receive regular provisions, as earlier attempts had failed when the explorers ran out of food. ${ }^{45}$

Upon encountering Gogy on this initial reconnaissance to find the site for the first depot, Barrallier believed that the 'native' had 'taken a fancy' to him. Meeting Gogy inspired Barrallier to employ a native guide, as he assumed that the Dharawal man would be 'useful to [him] when [he] advanced further inland' ${ }^{46}$ However, given Gogy's turbulent history with both the Dharawal and the Gandangara, it is likely that Gogy in turn saw an advantage in 'attaching' himself to the French surveyor. After having agreed that Gogy would serve as a guide on the eventual expedition, they arranged to rendezvous at Prospect Hill the following month.

The history of this failed expedition is well charted by historians, especially in local histories of the Blue Mountains. Barrallier set out with four soldiers, some convicts, and an ox-drawn cart, as well as Gogy and his wife and son. After establishing a depot, Barrallier and some of his men would generally set out on different excursions trying to make their way over the mountains by following the waterways.

43 Lhuedé 2003: 6-7.

44 Cunningham 1996: 98.

45 Barrallier 1975: 1.

46 Barrallier 1975: 1n. 
Over the course of the expedition other Gandangara men and some of their wives and families joined the expedition. Some of the men would guide Barrallier on his excursions, and their families would camp at the depots, exchanging goods and food. Yet Barrallier never found a passage across the mountains: on 17 December 1802, six weeks after setting out, and thoroughly frustrated by his futile excursions, Barrallier realised that the chain of mountains 'could only be ascended by making almost superhuman efforts' ${ }^{47}$ The next day he made his way back to the depot, and a few days later embarked on the threeday walk back to Sydney.

In his report to King, Barrallier frequently disparaged Gogy as 'useless'. This assessment has been echoed by both local historian Andy Macqueen and French studies scholar Valerie Lhuedé. They perceived Gogy's disturbingly violent treatment of his wife, and his seemingly erratic behaviour in general as 'obnoxious' and troublesome. ${ }^{48}$ Martin Thomas also suggested that the Gandangara's hostility towards Gogy 'undermined' Barrallier's expedition. ${ }^{49}$ Such interpretations are somewhat short-sighted, taking Barrallier at his word. Instead, it is most likely that in his journal, Barrallier, like many other European explorers, effaced the significant contribution Gogy made to the expedition.

Kathrin Fritsch observes that many European explorers tended to obscure the contribution of Indigenous intermediaries in their accounts by reducing them to the status of 'mere servants', and refusing to admit the 'native' knowledge that formed the basis of the geographic knowledge they produced. ${ }^{50} \mathrm{Her}$ argument is borne out in Barrallier's account, even though his account has a relatively unusual level of detail about the Aboriginal people he met, including their names, and many of the people he describes appear as individuals with distinct personalities and manners. Yet, even though Gogy was not rendered invisible like the intermediaries in Fritsch's case studies, Barrallier nonetheless reduced Gogy's role, describing him as a follower and not a guide, and treating him as a retainer. Further, in his detailed description of Aboriginal place names, local resources,

47 Barrallier 1975: 50.

48 Macqueen 1993: 94; Lhuedé 2003: 13.

49 Thomas 2003: 87.

50 Fritsch 2009. 
and cultural practices, he did not acknowledge Gogy as the source of information. For instance, on 6 November 1802, the first day of the expedition proper, Barrallier noted that the ford where they crossed the Nepean River was 'called Binhény by the natives', and that a swamp they arrived at later that day was known as 'Baraggel'. The next day they passed two more swamps called 'Manhangle' and 'Carabeely'. ${ }^{51}$ The French surveyor also reported that he had learned that these swamps teemed with 'enormous eels, fishes, and various species of shells', which were 'sometimes used by the natives as food', along with the 'opossums and squirrels, which are abundant in this country' ${ }^{52}$ Barrallier also described in detail the local method for hunting kangaroos: a large group would form a circle one or two miles across, and slowly moving inwards, corral the animals with fire and noise so that they could be more easily speared..$^{53}$ Yet by reading Barrallier's account against the grain, it becomes evident that his detailed local and cultural knowledge must have been explained to him by Gogy. The only other Aboriginal people in the party at that stage of the expedition was Gogy's wife and son, whom Barrallier rarely mentions. Barrallier's account, then, not only effaced Gogy's contribution to the local knowledge accumulated on the expedition, but also significantly masked the close relationship that the two men must have developed. The level of detail in his account suggests that the pair must have spent considerable time together conversing about their immediate environs, planning possible routes, and Aboriginal food sources and hunting practices.

Unlike Bennelong, Gogy has not been perceived as strategic by historians. Perhaps this is because Barrallier, Gogy's only significant chronicler, was himself oblivious to Gogy's motives. Phillip had eventually become partially aware of Bennelong's strategic endeavours throughout the course of their four-year affiliation. ${ }^{54}$ Barrallier on the other hand knew Gogy for less than two months, thus the motives behind Gogy's confusing actions remained opaque.

\footnotetext{
51 Barrallier 1975: 2.

52 Barrallier 1975: 2n.

53 Barrallier 1975: 2-3n.

54 Konishi 2007; Fullagar 2009.
} 
As we have seen, Gogy had quickly attached himself to Barrallier, and he arguably found this to be a privileged position that he alone wanted to hold, so jealously guarded it. As Alida Metcalf has observed in her study of Brazilian go-betweens, intermediaries 'inhabit an "in-between" space which gives them mobility, information and power', and as a consequence they 'may exploit their positions for their own benefit ${ }^{\prime} .^{55}$ Arguably, Gogy tried to create and inhabit the space between Barrallier and the other Aboriginal people, and use this 'in-between' space to his own advantage. This became apparent when the expedition encountered Bungin and Wooglemai, two Gandangara, or 'mountaineer', men as Barrallier called them. Bungin, who had never seen a white man before, quickly impressed Barrallier by demonstrating his expertise in discerning the identity of individuals by their footprints. He also showed gratitude to the Frenchman's generous trade of a new axe for Bungin's old one by building a hut for the Frenchman. This, Barrallier learned, was a local custom extended to 'strangers they wish to receive as friends', since ordinarily 'the natives do not allow any stranger to inhabit the territories they have appropriated to themselves'. ${ }^{56}$ Consequently, Barrallier decided to 'attach' himself to Bungin, believing he would be 'very useful in the country ... he was in', and attempted to curry his favour by ensuring food was given to him. ${ }^{57}$ As these exchanges and conversations would have been negotiated by Gogy, the expedition's sole translator at that point, it is most likely that he was conscious of his imminent displacement as the expedition's primary guide.

In response, Gogy tried to insinuate himself back into Barrallier's favour. His first opportunity soon arose when the expedition encountered new people: Bulgin and his wives and children. They had just been hunting and had in their possession two feet of an animal they called 'colo'. ${ }^{58}$ Knowing that Barrallier was interested in collecting natural history specimens, Gogy obtained these in exchange for two spears and a tomahawk, presumably his own since the only trade items Barrallier mentioned bringing on the expedition were metal axes. Barrallier was delighted with these specimens (most likely they were koala feet which he mistook for that of a monkey), and, in his own

\footnotetext{
55 Metcalf 2005: 3.

56 Barrallier 1975: 4-5.

57 Barrallier 1975: 5.

58 Barrallier 1975: 8-9.
} 
attempt to curry favour with Governor King, had them sent to him 'in a bottle of spirits'. That same night Gogy 'built for Barrallier a very large hut', perhaps as a reminder that before Bungin's arrival, he had a stronger friendship with the explorer. ${ }^{59}$ These gifts and ostensible symbols of friendship were arguably strategic attempts on Gogy's behalf to exploit mutual needs, and induce mutual accommodation. Like Bennelong's gifts, they were intended to induce reciprocity: Gogy had adapted the supposed local custom of building a hut as a sign of friendship by building a hut for Barrallier, even though he was not in his own territory, as custom dictated, and outperformed his rivals by building a very large one.

Towards the end of the Blue Mountains expedition, Gogy seemed especially determined to show Barrallier that his own allegiance was to the French surveyor and not the Gandangara 'natives'. As Barrallier repeatedly doubled-back to the depot after each failed excursion to find a route over the mountains, he frequently found that his huts had been burnt down or destroyed by the Gandangara people. In response to this, and arguably as a sign of his loyalty to Barrallier, 'Gogy set the country over which [they] were passing on fire to avenge [themselves] on the natives who had burnt [their] huts' ${ }^{60}$

Gogy's motive for fostering a close alliance with Barrallier, not to mention the four redcoats who accompanied the expedition, was to forge an alliance with the British against the Gandangara, much like Bennelong seemed to do with Phillip against the Cameragal. On 12 November, Bungin discovered a group of Gandangara men including Gogy's enemy Goondel sitting around a fire. Bungin approached them in a reassuring manner, 'telling them not to be frightened' and that the white men 'were travelling without any intention of doing them any harm' ${ }^{61}$ Gogy followed, but instead of placating the Gandangara men he 'held [Barrallier's] gun in his hand to show them he could make use of the [British] arms' ${ }^{62}$ This threatening demonstration of his superior weapon and allies was perhaps Gogy's main motivation for agreeing to guide Barrallier into the territory of the enemy he had previously fled. However, Gogy's aggressive

\footnotetext{
59 Barrallier 1975: 9 (my emphasis).

60 Barrallier 1975: 45.

61 Barrallier 1975: 15-16.

62 Barrallier 1975: 16.
} 
performance did not elicit the reaction he intended: the men refused to speak to Gogy, and instead threw 'terrible glances at him' and deliberately excluded him from a share in their meal, a gesture that Gogy considered 'as the greatest insult'. ${ }^{63}$

Unable to create an alliance between himself and Barrallier against the Gandangara, Gogy changed tactic, and tried to prevent Barrallier from having further contact with Goondel and his men. He begged Barrallier not to camp near them, claiming that they would kill Gogy in his sleep despite the presence of armed sentries. Later in the expedition, whenever they happened upon Goondel or his men Gogy would 'insist that they must not disturb him' and encourage the expedition to move on. Towards the end of the journey, on 14 December, when they were in Gandangara country, Gogy exclaimed that they were about to enter the territory of a new tribe who 'were anthropophagi' and that 'they ought not to try and mix with them' ${ }^{64}$ Bennelong and other Port Jackson Aboriginal people had similarly launched exaggerated accusations against neighbouring Aboriginal people in order to dissuade the British from approaching them. ${ }^{65}$ When Barrallier laughed at Gogy's apparently tall tale, he grew angry and retorted: 'Well master, you will see that I am not a liar. ${ }^{66}$ Yet the next day, instead of discovering the apocryphal tribe of cannibals as they ventured further into the mountains, they again happened upon Goondel.

Like Bennelong, Gogy's most shocking and perplexing performance was a violent assault on a woman, his wife. One month earlier, on 14 November, while they waited at the depot for their supplies, Gogy unexpectedly flew into a rage when his wife ate some 'morsels' of food given to his son. He suddenly 'took his club and struck his wife's head such a blow that she fell to the ground unconsciously'. Ignoring the others' attempts to pacify him, Gogy paced around, all the while 'abusing his wife', and then rushed back, stabbing her in the thigh

\footnotetext{
63 Barrallier 1975: 17.

64 Barrallier 1975: 47.

65 For instance Bennelong had told Phillip that the Botany Bay people 'always kill the white men', which eventually led 'Governor Phillip ... to suspect, though very unwillingly, that there was a great deal of art and cunning in Bennelong', and the Port Jackson Aboriginal people reported to the British that the Botany Bay man 'Gòme-boak was a cannibal'. Phillip 1968: 327; Collins 1975, I: 342.

66 Barrallier 1975: 47n.
} 
with his fishing spear several times, and then grabbed a musket and threatened to shoot her. After a short interlude in which Bungin attempted to calm him down, Gogy 'walk[ed] up and down in a great fury', everyone cowering in his wake. Finally, Gogy went to Barrallier and 'said he was almost certain one of [Barrallier's] people had seduced his wife'. The Frenchman replied that this 'was impossible' and it was only his 'state of anger which made him believe things that did not exist'. However, this did not placate Gogy and he again struck his wife, who then revealed that the seducer was 'Withington, one of [the] soldiers' and assured him that 'she had never responded to his advances'. Barrallier did not put much faith in her testimony, instead commenting that in general 'cruelty and laziness are two prominent characteristics of the natives' ${ }^{67}$

Scholars have deplored Gogy's violent attack on his wife and, like Barrallier, construed it as an example of how male violence against women has been 'a feature for Aboriginal culture since long before the First Fleet'. ${ }^{68}$ However, even though this was a shockingly brutal incident, it cannot be explained by the ostensibly violent nature of Aboriginal gender relations. ${ }^{69}$ Again, Gogy's performance is reminiscent of Bennelong's protracted and violent attack on the young woman Boorong in front of the British officers and Governor Phillip, in retaliation of a crime committed against him by her father. ${ }^{70}$ Both attacks appeared to have been flagrant and defiant aggressive acts performed in front of the colonists, whom in both instances claimed to pity the women but failed to intervene. Further, both Bennelong and Gogy demonstrated their power over women, perhaps to show the newcomers that they still exerted some authority within their own domestic polity in spite of the colonial authority of the governor and expedition leader. However, I suspect that Gogy's charge that one of white men had wronged him by seducing his wife was his attempt to make Barrallier beholden to him and allow him to demand retribution.

67 Barrallier 1975: 22-23.

68 Thomas 2013. See also Lhuedé 2003: 13. However, in response to similar charges made by Manning Clark, Macqueen points out that Bungin, Gogy's competitor for Barrallier's esteem, tenderly dressed Gogy's wife's wounds, and in the following days Gogy 'looked sorry for having ill-treated, his wife', and was 'very affectionate towards her'. Macqueen 1993: 96.

69 For a more detailed discussion of colonial tropes about Aboriginal gendered violence, see Konishi 2008.

70 See Konishi 2012: 60 . 


\section{Conclusion: The parallel lives of two strategic brokers}

In 1792 Phillip completed his term as governor and voyaged back to Britain. Bennelong accompanied him there, along with Yemmerawanne, and they were the first Australian Aboriginal people to venture to Europe. Bennelong stayed in Britain for two years; sadly, Yemmerawanne died after the first. During his stay Bennelong visited key sites of Britain's power, culture and history - the Houses of Parliament, St Paul's Cathedral and the Tower of London - but was determined to return home. ${ }^{71}$ After his homecoming in September 1795, Bennelong was reported to have initially 'assumed the manners, the dress, and the consequence of an European', but ultimately 'returned to his old habits', living 'in the same manner as those who never mixed with the civilised world' until his demise in January $1813 .{ }^{72}$ Yet after his return he no doubt had little interest in mixing with the 'civilised world' as he, Bennelong, continued to occupy a 'respected position in the Eora clan networks' ${ }^{73}$ playing significant roles in gatherings of the Eora clans, and the ceremonial punishment of transgressors.

After failing to find a route through the mountains, Barrallier returned to Sydney, where he soon fell out of favour with Governor King and abruptly left the colony. Gogy remained an outlaw and continued to transgress Aboriginal law. He was ritually punished by Bennelong in 1805, receiving two seemingly mortal spear wounds which he remarkably recovered from (as described in the epigraph). ${ }^{74}$ Unlike Bennelong, he continued to try to strategically attach himself to various colonists. Such endeavours served him well in 1816 during Governor Macquarie's punitive raids against the Gandangara, for his old friend John Warby and Charles Throsby protected Gogy from the soldiers who mistook Gogy for a 'hostile native', allowing him to flee to Botany Bay. ${ }^{75}$ At this point he disappeared from colonial records, however, in February 1824 French explorer Dumont D'Urville observed a large gathering of the Eora clans from 'Parramatta, Kissing Point, Sydney,

\footnotetext{
71 Fullagar 2009: 31.

72 David Mann, The Present Picture of New South Wales, London, 1811, 46-47, cited in Smith 2009: 19.

73 Smith 2009: 22.

74 Sydney Gazette and New South Wales Advertiser, 17 March 1805, 7 April 1805.

75 Liston 1988: 52.
} 
Liverpool, Windsor, Emu Plains, Broken Bay, Five islands, Botany Bay, and even from Hunter River etc. etc.' and observed that the 'Liverpool tribe [was] commanded by Coagai [Gogy]'. This time, as opposed to being the transgressor, Gogy was there to see the punishment of eight individuals who had killed an ally of his from the Windsor clan. ${ }^{76}$ Thus, like Bennelong, Gogy also eschewed close contact with the British once he had managed to occupy an esteemed position within Aboriginal society.

Through a comparison with Bennelong, who is well recognised as political and strategic, I suggested motivations for Gogy's 'attachment' to Barrallier and re-read his behaviour as tactical, as opposed to erratic and obnoxious as previous scholars have claimed. I have also tried to tease out Bennelong's and Gogy's individual personalities, to show that Indigenous responses to the colonial presence were idiosyncratic. This was especially the case in the early stages of the colony, when the conditions still allowed for a nascent 'middle ground' to exist; that is a time when there was still a rough balance of power between Indigenous people and colonists, and intermediaries served important functions in negotiating their mutual needs and accommodation. ${ }^{77}$ Such histories reveal that the early history of cross-cultural interaction in Australia was not just one of colonial oppression and Indigenous resistance, but shaped by myriad interpersonal encounters influenced by complex and individual relationships and interests. By considering the process of mediation in these early New South Wales encounters, this chapter provides insights into how Indigenous individuals such as Bennelong and Gogy saw the presence of the newcomers as an opportunity to remake themselves, and to attempt to elevate their status and power within their local Indigenous society.

\section{References}

Aboriginal Heritage Office 2015, Filling a Void: A Review of the Historical Context for the Word 'Guringai', Aboriginal Heritage Office, North Sydney.

76 Dumont D'Urville 1987: 85.

77 White 2011: xii. 
Barrallier, Francis 1975, Journal of the Expedition into the Interior of New South Wales 1802, by Order of His Excellency Governor Philip Gidley King, by Francis Barrallier, Ensign, New South Wales Corps, Marsh Walsh Publishing, Melbourne.

Clendinnen, Inga 2003, Dancing with Strangers, Text Publishing, Melbourne.

Collins, David 1975, An Account of the English Colony in New South Wales, B. Fletcher (ed.), 2 vols, A.H. \& A.W. Reed in association with the Royal Historical Society, Sydney.

Cunningham, Chris 1996, Blue Mountains Rediscovered: Beyond the Myths of Early Australian Exploration, Kangaroo Press, Kenthurst.

Dictionary of Sydney n.d., 'Cameragal people', www.dictionaryof sydney.org/organisation/cameragal_people, accessed 1 February 2016.

Dortins, Emma 2009, 'The many truths of Bennelong's tragedy', Aboriginal History 33: 53-75.

Dumont D'Urville, Jules S.-C. 1987, An Account in Two Volumes of Two Voyages to the South Seas by Captain Jules S-C Dumont D'Urville of the French Navy to Australia, New Zealand, Oceania 1826-1829 in the corvette Astrolabe and to the Straits of Magellan, Chile, Oceania, South East Asia, Australia, Antarctica, New Zealand and Torres Strait 1837-1840 in the corvettes Astrolabe and Zélée, Vol. 1: Astrolabe 1826-1829, Helen Rosenman (trans. and ed.), Melbourne University Press, Carlton, 1987.

Fritsch, Kathrin 2009, "You have everything confused and mixed up...!" Georg Schweinfurth, knowledge and cartography of Africa in the 19th century', History in Africa 36(1): 87-101.

Fullagar, Kate 2009, 'Bennelong in Britain', Aboriginal History 33: 31-52.

Kennedy, Dane 2013, The Last Blank Spaces: Exploring Africa and Australia, Harvard University Press, Boston.

King, Philip G. 1968 [1793], 'Lieutenant King's Journal', in John Hunter, An Historical Journal of Events at Sydney and at Sea, 17871792, by Captain John Hunter, Commander H.M.S. Sirius, with 
further Accounts by Governor Arthur Phillip, Lieutenant P.G. King, and Lieutenant H.L. Ball, John Bach (ed.), Angus and Robertson, Sydney.

Konishi, Shino 2007, 'The father Governor: the British administration of Aboriginal people at Port Jackson, 1788-1792', in Public Men: Masculinity and Politics in Modern Britain, Matthew McCormack (ed.), Palgrave Macmillan, Hampshire, 54-61.

2008, "Wanton with plenty": Questioning ethno-historical constructions of sexual savagery in Aboriginal societies, 1788-1803', Australian Historical Studies 39(3): 356-372.

2012, The Aboriginal Male in the Enlightenment World, Pickering and Chatto, London.

Lhuedé, Valerie 2003, 'Francis Barrallier, explorer, surveyor, engineer, artillery officer, aide-de-camp, architect and ship designer: Three years in New South Wales (1800-1803)', Explorations: A Journal of French-Australian Connections 35.

Liston, Carol 1988, 'The Dharawal and Gandangara in colonial Campbelltown, New South Wales, 1788-1830', Aboriginal History 12(1): 58 .

Macqueen, Andy 1993, Blue Mountains to Bridgetown: The Life and Journeys of Barrallier, 1773-1853, A. Macqueen, Springwood.

Metcalf, Alida C. 2005, Go-Betweens and the Colonization of Brazil: 1500-1600, University of Texas Press, Austin.

Phillip, Arthur 1968 [1793], 'Phillip's Journal', in John Hunter, An Historical Journal of Events at Sydney and at Sea, 1787-1792, by Captain John Hunter, Commander H.M.S. Sirius, with further Accounts by Governor Arthur Phillip, Lieutenant P.G. King, and Lieutenant H.L. Ball, John Bach (ed.), Angus and Robertson, Sydney.

Reynolds, Henry 1990, With the White People, Penguin Books, Ringwood, Vic.

Russell, Lynette 2001, 'The instrument brings on voices: Writing a biographical history', Meanjin 60(3): 142-151. 
Smith, Keith Vincent 2009, 'Bennelong among his people', Aboriginal History 33: 7-30.

Sydney Gazette and New South Wales Advertiser.

Tench, Watkin 1979 [1789-1793], Sydney's First Four Years: being a reprint of $A$ Narrative of the Expedition to Botany Bay and A Complete Account of the Settlement at Port Jackson, L.F. Fitzhardinge (ed.), Library of Australian History in association with the Royal Australian Historical Society, Sydney.

Thomas, Martin 2003, The Artificial Horizon: Imagining the Blue Mountains, Melbourne University Press, Melbourne.

Thomas, Tony 2013, 'The long history of Aboriginal violence-Part II', Quadrant, 7 May.

Turnbull, David 2009, 'Boundary-crossings, cultural encounters and knowledge spaces in early Australia', in The Brokered World: Go-Betweens and Global Intelligence 1770-1820, Simon Schaffer, Lissa Roberts, Kapil Raj and James Delbourgo (eds), Science History Publications, Sagamore Beach, MA, 387-428.

White, Richard 2011, The Middle Ground: Indians, Empires, and Republics in the Great Lakes Region, 1650-1815, Twentieth Anniversary Edition, Cambridge University Press, Cambridge. 
This text is taken from Brokers and Boundaries: Colonial Exploration in Indigenous Territory, edited by Tiffany Shellam, Maria Nugent, Shino Konishi and Allison Cadzow, published 2016 by ANU Press, The Australian National University, Canberra, Australia. 